\title{
Problems in Umbilical Cord Blood Collection
}

\author{
Carolyn Troeger ${ }^{a}$ Sandrine Meyer-Monard ${ }^{b} \quad$ André Tichelli $^{b} \quad$ Gwendolin Manegold $^{a}$ \\ Doris Paulia ${ }^{\mathrm{a}}$ Daniel Surbek ${ }^{\mathrm{c}}$ Wolfgang Holzgreve ${ }^{\mathrm{a}}$ Nicole Bürki $^{\mathrm{d}}$ \\ a Department of Obstetrics and Gynecology, \\ ${ }^{b}$ Department of Hematology, University Hospital Basel, \\ ${ }^{c}$ Department of Obstetrics and Gynecology, University Hospital Bern, \\ dDepartment of Obstetrics and Gynecology, Cantonal Hospital Liestal, Switzerland
}

\section{Key Words \\ Cord blood sampling · Donor selection}

\section{Summary}

Introduction: The goal of the Cord Blood Bank Basel is to provide umbilical cord blood (UCB) for allogeneic stem cell transplantations from unrelated donors. Our registry contains 1,044 units, 12 have been released for transplantation (1\%). In the past collection mainly took place at the Women's Hospital Basel, where only $10 \%$ of deliveries resulted in HLA-typed and frozen transplants. The aim of our study was to evaluate the high deferral rate. Materials and Methods: During a 4-week period we assessed every delivery at our hospital by a questionnaire on patient data, consent procedure, inclusion or exclusion criteria and reasons for performing or not performing UCB collection. Results: 164 women delivered at our institution (135 vaginal deliveries, 29 cesarean sections). Among these, 131 were eligible for autologous UCB donation, whereas 33 women had to be excluded due to their medical history (26), triplet delivery (1), post partum hemorrhage (1), congenital malformation (1) or chorioamnionitis (4). Of the eligible women, 17 refused donating UCB, and 29 women underwent a cesarean section. 11 women were admitted under painful contractions. 18 had to be rejected due to lack of laboratory facilities at the weekend. Finally, 43 UCB samples had been taken, 2 for private banking purposes $(4.6 \%), 21$ (48.8\%) for the public bank, and 20 samples (46.5\%) which had to be discarded due to a low cell count. Conclusions: Donor selection is efficiently performed before the collection process. The rate of donor deferral and UCB sample discard is high and comparable to other UCB banks. The yield of UCB transplants could be increased if UCB collection would be additionally performed during cesarean section and with increased laboratory facilities during the weekend.

\section{Schlüsselwörter \\ Spenderauswahl · Nabelschnurblutentnahme}

\section{Zusammenfassung}

Einführung: Das Ziel der Nabelschnurblutbank Basel ist es, Nabelschnurblut(UCB)-Stammzelltransplantate von unverwandten Spendern zur Verfügung zu stellen. Momentan sind 1044 Transplantate registriert. Bisher fand die UCB-Entnahme an der Universitäts-Frauenklinik Basel statt, wobei zirka 10\% der Geburten zu einem HLA-typisierten Transplantat führten. Unsere jetzige Studie soll die hohe Rückweisungsquote näher untersuchen. Material und Methoden: Während 4 Wochen haben wir bei jeder Geburt in unserer Einrichtung Patientendaten, Einverständnisprozeduren, Einund Ausschluss der Patientin und Gründe für die Entnahme respektive Nichtentnahme von UCB erhoben. Ergebnisse: 164 Frauen haben in unserer Klinik entbunden (135 Vaginalgeburten, 29 Sectiones). Von diesen erfüllten 131 Frauen die Kriterien für eine UCB-Spende, während 33 Frauen aufgrund ihrer Anamnese (26), einer Drillingsgeburt (1), einer schweren postpartalen Hämorrhagie (1), einer kongenitalen Fehlbildung (1) bzw. einer Chorioamnionitis (4) ausgeschlossen wurden. Von den 131 geeigneten Frauen gaben 17 keine Zustimmung zur Entnahme, 29 wurden per Sectio entbunden, 11 kamen mit schmerzhaften Wehen. 18 UCBEntnahmen konnten aufgrund fehlender Laborkapazität am Wochenende nicht durchgeführt werden. Schließlich wurde bei 43 Frauen eine UCB-Entnahme durchgeführt, von denen 2 in einer privaten autologen Bank $(4,6 \%)$ und $21(48,8 \%)$ in einer allogenen Bank gelagert wurden; 20 Proben $(46,5 \%)$ mussten aufgrund zu geringer Zellzahl zurückgewiesen werden. Schlussfolgerungen: Die Donorselektion erfolgt effizient und kostensparend bereits vor der Entnahme. Die Rückweisungsrate ist hoch und mit anderen Nabelschnurblutbanken vergleichbar. Die Ausbeute an UCB-Transplantaten könnte durch eine Entnahme bei Sectiones sowie eine Ausweitung der Laborkapazitäten während des Wochenendes erhöht werden.

\begin{tabular}{ll}
\hline KARGER & @ 2007 S. Karger GmbH, Freiburg \\
$\begin{array}{l}\text { Fax +497614520714 } \\
\begin{array}{l}\text { E-mail Information@Karger.de } \\
\text { www.karger.com }\end{array}\end{array}$ & $\begin{array}{c}\text { Accessible online at: } \\
\text { www.karger.com/tmh }\end{array}$ \\
&
\end{tabular}

Dr. med. Carolyn Troeger 


\section{Introduction}

The collection, storage and transplantation of stem cells derived from umbilical cord blood (UCB) has become a routine procedure and represents a good alternative to bone marrow and peripheral blood mobilized stem cells. Comparable to these, UCB stem cells are used to treat malignant and nonmalignant hematological diseases, congenital immunodeficiencies and solid tumors. The advantages of UCB stem cells, namely the fast availability of HLA-typed frozen transplants, their immunological immaturity and their high proliferative and seeding capacity, led to the establishment of public UCB banks worldwide where more than 150,000 UCB units are stored [1]. More than 5,000 UCB transplantations have been performed worldwide, not only in children but also in adults who now account for about one third of all recipients [2]. Especially in adults, the limited cell number in UCB is a significant issue, as $3-3.5 \times 10^{7}$ nucleated cells $/ \mathrm{kg}$ are needed at minimum for a successful UCB transplantation [3, 4]. But only $12 \%$ of the current inventories in established public UCB banks contain sufficient cells to transplant patients weighing more than $60 \mathrm{~kg}$ [5].

Several studies have shown that cell numbers in UCB are increased under certain instances, e.g. gestational age and birth weight, early cord clamping, operative deliveries, prolonged labor, low $\mathrm{pH}$ at delivery, Caucasian or Hispanic ethnicity, male sex [6-10]. Since the cell dose is correlated with the speed of engraftment and overall treatment success, strict criteria are set for UCB samples to be accepted for an allogeneic UCB bank. Required numbers of nucleated cells increased from the beginning of UCB transplantation from $2.1 \times 10^{8}$ to $10 \times 10^{8}$ nucleated cells nowadays [11-14]. These high cell numbers lead to a relatively high deferral rate of UCB samples ranging from 20 to $90 \%[12,15,16]$.

Though limited cell numbers in UCB are the major cause to discard a UCB sample, there are other significant problems in recruiting UCB donors before drawing the UCB that are not well studied. At our institution over the years only $10 \%$ of deliveries resulted in registered UCB transplants. This study aims to analyze the reasons for deferral of donors before UCB is sampled and for discard of UCB units in order to optimize the UCB sampling efficacy.

\section{Materials and Methods}

\section{Recruitment and UCB Collection}

UCB collection for the Cord Blood Bank Basel has been initiated in 1997, and our effort was approved by the local ethics committee. All steps from the recruitment of women to the processing and registration of $\mathrm{UCB}$ transplants are performed according to standard operating procedures (SOP) and guidelines edited by the Foundation for Accreditation of Hematopoietic Cellular Therapy (FACT).

Optimally, recruitment for UCB donation takes place during the prenatal visit at the outpatient department of our institution or, if not yet informed by the referring gynecologist, during the admission to our labor ward.
Healthy pregnant women are eligible for UCB donation if they and their partners have an unremarkable medical and family history, no risk of infectious diseases (HIV, Creutzfeldt-Jakob disease, malaria, etc.) due to their behavior and recent stay in areas with high prevalence of these infectious diseases as well as negative serological testing for HIV, hepatitis $\mathrm{B}$, toxoplasmosis and syphilis during pregnancy. Any chorioamnionitis, severe maternal bleeding or fetal malformations are exclusion criteria for UCB sampling. Informed consent is obtained before delivery and in the absence of painful contractions that might hinder a sufficient decision making. If the pregnant woman consents, UCB sampling is undertaken after delivery of the infant, after which we routinely perform early cord clamping and administration of a bolus injection of 5 IU of oxytocin. These procedures are routinely used to prevent severe post partum hemorrhage. If the woman wants to leave the cord unclamped until any pulsation stops, UCB sampling is not performed. UCB sampling is performed by the obstetrician who is also responsible for the delivery itself. The placenta is still in utero, and the umbilical vein is punctured near the cord clamp with a UCB collection system (Macopharma, Unepharma S.A. Mouscron, Zuchwil, Switzerland) by gravity after disinfection using an alcohol-iodine solution. UCB sampling is performed only after vaginal deliveries, because UCB sampling during cesarean section is recently not feasible due to a lack in sterile collector bags that meet the sterility criteria for use on the operating table. Moreover, ex utero sampling by not specifically trained personal usually revealed a low cell count.

Units with an estimated weight of more than $100 \mathrm{~g}$ (collector bag with UCB and $35 \mathrm{ml}$ citrate-phosphate-dextrose-adenine) determined in the labor room are sent within $6 \mathrm{~h}$ to the stem cell laboratory of the department of hematology and stored at $4{ }^{\circ} \mathrm{C}$ until further processing which takes place within $24 \mathrm{~h}$. Laboratory facilities are available between Monday morning and Friday afternoon. Accordingly, UCB collection is performed between Sunday morning and Friday noon. The total number of nucleated cells is determined using a Coulter Counter. If a minimum of $8 \times 10^{8}$ nucleated cells are collected, the UCB sample is further processed and stored.

We performed a prospective study within a 4-week period (from August 20 to September 16, 2006) to evaluate the reasons for deferral of donors and discard of UCB samples before processing. The obstetrician in charge had to fill out a questionnaire after every delivery. Here, we assessed donor eligibility, UCB sampling, and reasons for not sampling.

\section{Results}

The Cord Blood Bank Basel contains 1,044 samples that are registered at the national stem cell registry. 12 UCB transplants have been released for allogeneic UCB transplantation (1\%). Additional 122 UCB samples in the inventory of our bank consist of 52 samples for family-directed UCB transplantation. Another 25 samples are not yet ready for registration. 45 UCB samples $(3.8 \%)$ had to be discarded after processing due to quality issues (positive maternal serological testing, bacterial contamination, technical issues).

During the study period 164 deliveries took place at our labor room. 131 women $(79.9 \%)$ were eligible for UCB donation, and 43 cords could be collected. From the eligible patients, 88 cords could not be collected: 29 underwent a cesarean section, 18 delivered during a weekend when the stem cell laboratory had no facilities, and 17 patients gave no consent (table 1). Of the 33 women who were not eligible for UCB sampling, 26 had to be excluded due to their medical history or risk behav- 
Table 1. Reasons for not collecting or processing of UCB in 108 of 131 eligible patients (21 allogeneic UCB and 2 autologous UCB not included)

\begin{tabular}{lrc}
\hline Reason & Number & Percentage \\
\hline Workload & 9 & 8.3 \\
Cesarean section & 29 & 26.8 \\
Preterm & 2 & 1.9 \\
Contractions & 11 & 10.2 \\
Twins & 2 & 1.9 \\
No consent & 17 & 15.7 \\
Weekend & 18 & 16.7 \\
Low cell count/volume & 20 & 18.5 \\
\cline { 2 - 3 } Total & 108 & 100.0 \\
\hline
\end{tabular}

Table 2. Reasons for donor deferral $(\mathrm{n}=33)$

\begin{tabular}{lrc}
\hline Reason & Number & Percentage \\
\hline Chorioamnionitis & 4 & 12.1 \\
Medical history & 26 & 78.8 \\
Fetal malformation & 1 & 3.0 \\
Triplet & 1 & 3.0 \\
Post partum & & \\
$\quad$ hemorrhage & 1 & 3.0 \\
\cline { 2 - 3 } Total & 33 & 100.0 \\
\hline
\end{tabular}

ior (i.v. drug abuse, multiple sexual partners, tattooing or piercing under nonsterile condition, etc.) or recent stay in countries with a high prevalence of certain infectious diseases, i.e. malaria, Creutzfeldt-Jakob disease as assessed by the questionnaire (table 2). From the 43 collected UCB samples, 6 were not send to the stem cell laboratory because of low volume, and 14 were rejected by the laboratory due to low cell count. 2 UCB samples were collected for an autologous private UCB bank. Finally, 21 UCB samples (12.8\%) were processed and stored frozen.

\section{Discussion}

UCB stem cells are increasingly used for hematopoietic stem cell transplantation in children and adults. Accordingly, since the first transplantation in 1988 many public UCB banks have been established worldwide. However, quality issues have come up only recently [17-19]. UCB banks voluntary follow certain guidelines for collection, processing, and cryopreservation. All procedures are strongly regulated in SOP and precisely documented. As a result of this process quality requirements have increased over time, and units that had been suitable before may no more be sufficient today. As a consequence, the quality of the UCB units for stem cell transplantation improved, but in the same setting donor eligibility decreased and discards of UCB samples have increased.

The aim of our study was to evaluate possible problems in donor selection and UCB collection during a short-time period to be able to improve our process. In reviewing the rela- tionship between the number of deliveries at the collection site and the number of transplants retrieved, we noticed that only about $10 \%$ of deliveries result in registered UCB units. Our results show that the majority of our patients in the delivery room would be eligible for UCB donation. The main cause for omitting UCB sampling at our institution is a cesarean section where we have noticed rather low cell numbers when collection takes place from the placenta ex utero (data not shown). This is the reason why we do not consider patients with cesarean section for UCB collection at the moment. This statement is in contrast to the evidence in the literature and our own former experiences that retrieved cell numbers are elevated in cesarean sections $[7,9,20]$. However, these results were obtained using either a separate person to perform UCB sampling only and without time delay or using a sterile collector bag on table directly after delivery of the baby. At the moment there are no sterile collection sets available in Switzerland that would meet the sterility standards of our hospital. Moreover, there is no separate person for UCB collection only. The midwife primarily takes care for the infant after delivery which leads to a relatively long time span between cord clamping and UCB collection, resulting in very low numbers of nucleated cells. Whether cell number is a critical issue in both primary and secondary cesarean section is currently under investigation to adjust our policy.

Other reasons for not collecting UCB in eligible patients are a delivery at a time when the processing laboratory is closed $(16 \%)$ or the fact that the pregnant women have not given consent $(16 \%)$. These two factors can hardly be influenced. Most UCB banks collect UCB between Sunday and Friday to allow processing of the unit within $24 \mathrm{~h}$, and a prolongation of the working period of the laboratory would significantly increase personnel costs [21]. Storage of UCB longer than $24 \mathrm{~h}$ would decrease the yield of nucleated cells and CD34+ cells [22]. The consent procedure at our institution usually takes place during the routine outpatient pregnancy visits around 4 weeks before the estimated date of delivery or when the patient in labor is pain-free due to an epidural anesthesia in the 1st stage of labor. In contrast to other institutions and in accordance with the FACT guidelines, we do not perform any UCB sampling without consent before delivery. The sampling is performed with the placenta still in utero by the obstetrician who is also responsible for the delivery and cannot leave the delivery room to collect blood ex utero in a separate room $[15$, 23]. Thus, the ex utero technique is not applicable, but to collect UCB first and ask for consent afterwards is unethical not only in our opinion [24]. This statement relates not only to the collection procedure itself but also to the extensively required medical and personal information and the disclosure of abnormal results in the blood of infant or mother, where sufficient information should be given to the mother beforehand.

These above mentioned issues lead to a relatively high rate of cases where either no UCB sampling is performed (54\%) or donation is deferred, mainly because of the maternal medical 
history $(20 \%)$. These observations are in accordance with other UCB banks which had deferral rates as high as ours [14, $15,25,26]$. From the UCB samples collected, about half have a nucleated cell count lower than the current standard. This is in accordance with the information given by other UCB banks where low cell count is found in $2-80 \%$ of samples $[12,14,15]$. Since at our institution the obstetrician in charge, and not a separate experienced collector, is responsible for both the delivery and the UCB sampling, continuous training and quality control is an ongoing issue.

In summary, our results show that the donor selection in the Cord Blood Bank Basel is feasible and efficiently uses the re- sources because donor deferral mainly takes place before UCB is collected. Most women admitted for delivery are eligible for UCB donation. However, several logistic problems such as UCB sampling in cesarean section or restricted laboratory facilities are reasons not to collect UCB in a considerable part of these women. Within the collected UCB samples, low cell count is the major quality issue leading to discard in about half of the samples. This number could only be decreased when obstetrical factors (such as fetal weight or operative delivery) that are known to increase cell number would be used to further select donors. But every further selection would most probably decrease the number of stored UCB samples.

\section{References}

1 Gluckman E, Rocha V: Cord blood transplant: strategy of alternative donor search. Springer Semin Immunopathol 2004;26:143-54.

2 Steinbrook R: The cord-blood-bank controversies. N Engl J Med 2004;351:2255-2257.

3 Rocha V, Labopin M, Sanz G, Arcese W, Schwerdtfeger R, Bosi A, Jacobsen N, Ruutu T, de Lima M, Finke J, Frassoni F, Gluckman E; Acute Leukemia Working Party of European Blood and Marrow Transplant Group; Eurocord-Netcord Registry: Transplants of umbilical-cord blood or bone marrow from unrelated donors in adults with acute leukemia. N Engl J Med 2004;351:2276-85.

-4 Gluckman E, Rocha V, Arcese W, Michel G, Sanz G, Chan KW, Takahashi TA, Ortega J, Filipovich A, Locatelli F, Asano S, Fagioli F, Vowels M, Sirvent A, Laporte JP, Tiedemann K, Amadori S, Abecassis M, Bordigoni P, Diez B, Shaw J, Vora A, Caniglia M, Garnier F, Ionescu I, Garcia J, Koegler G, Rebulla P, Chevret S; Eurocord Group: Factors associated with outcomes of unrelated cord blood transplant: guidelines for donor choice. Exp Hematol 2004;32:397-407.

5 Kurtzberg J, Drapkin Lyerly A, Sugarman J: Untying the Gordian knot: policies, practices, and ethical issues related to banking of umbilical cord blood. J Clin Invest 2005;115:2592-2597.

6 Nakagawa R, Watanabe T, Kawano Y, Kanai S, Suzuya H, Kaneko M, Watanabe H, Okamoto Y, Kuroda Y, Nakayama T; Chugoku-Shikoku Cord Blood Bank: Analysis of maternal and neonatal factors that influence the nucleated and CD34+ cell yield for cord blood banking. Transfusion 2004; 4(2):262-7.

7 Cairo MS, Wagner EL, Fraser J, Cohen G, Van de Ven C, Carter SL, Kernan NA, Kurtzberg J: Characterization of banked umbilical cord hematopoietic progenitor cells and lymphocyte subsets and correlation with ethnicity, birth weight, sex, and type of delivery: a Cord Blood Transplantation (COBLT) Study report. Transfusion 2005;45: 856-866.
8 Aroviita P, Teramo K, Hiilesmaa V, Kekomäki R: Cord blood hematopoietic progenitor cell concentration and infant sex. Transfusion 2005;45:613-621.

$\checkmark 9$ Aufderhaar U, Holzgreve W, Danzer E, Tichelli A, Troeger C, Surbek DV: The impact of intrapartum factors on umbilical cord blood stem cell banking. J Perinat Med 2003;31:317-22.

10 Yao AC, Moinian M, Lind J: Distribution of blood between infant and placenta after birth. Lancet 1969;ii:871-873.

11 Laughlin MJ, Barker J, Bambach B, Koc ON, Rizzieri DA, Wagner JE, Gerson SL, Lazarus HM, Cario M, Stevens CE, Rubinstein P, Kurtzberg J: Hematopoietic engraftment and survival in adult recipients of umbilical cord blood from unrelated donors. N Engl J Med 2001;344:1815-1822.

12 Lecchi L, Ratti I, Lazzari L, Rebulla P, Sirchia G: Reasons for discard of umbilical cord blood units before cryopreservation. Transfusion 2000;40: 122-123.

13 Davey S, Armitage S, Rocha V, Garnier F, Brown J, Brown CJ, Warwick R, Fehily D, Watt S, Gluckman E, Vora Y, Contreras M, Navarrete CV: The London Cord Blood Bank: analysis of banking and transplantation outcome. Br J Haemotol 2004;125: 358-365.

14 Kurtzberg J, Cairo MS, Fraser JK, Baxter-Lowe L, Cohen G, Carter SL, Kernan NA: Results of the Cord Blood Transplantation (COLBT) Study unrelated donor banking program. Transfusion 2005;45: 842-855.

15 Stanworth S, Warwick R, Fehily D, Persaud C, Armitage S, Navarrete C, Contreras M: An international survey of unrelated umbilical cord blood banking. Vox Sang 2001;80:236-243.

16 Tamburini A, Malerba C, Picardi A, Amadori S, Calugi A: Placental/umbilical cord blood: experience of St. Eugenio Hospital Collection Center. Transplant Proc 2005;37:2670-2672.

17 Gluckman E: Hematopoietic stem-cell transplants using umbilical-cord blood: N Engl J Med 2001;344: 1860-1861.
8 Rubinstein P: Why cord blood? Hum Immunol 2006;67:398-404.

19 Ballen K, Broxmeyer HE, McCullough J, Piaciabello W, Rebulla P, Verfaillie CM, Wagner JE: Curren status of cord blood banking and transplantation in the United States and Europe. Biol Blood Marrow Transpl 2001;7:635-645.

20 Shlebak AA, Roberts IAG, Stevens TA, Syzdlo RM, Goldman JM, Gordon MY: The impact of antenatal and perinatal variables on cord blood haematopoietic stem/progenitor cell yield available for transplantation. Br J Haemotol 1998;103: 1167-1171.

21 Sirchia G, Rebulla P, Tibaldi S, Lecchi L: Cost of umbilical cord blood units relased for transplantation. Transfusion 1999;39:645-650.

22 Lee YH, Han JY, Choi AH, Lee HS, Hur WJ, Seo SY, Han H, Kim JS, Kim HJ: The alterations of the activities of coagulation inhibitors and fibrinolytic factors in stored cord blood could affect the yield of progenitor cells during processing. J Hematother Stem Cell Res 1999;8:653-657.

23 Vawter DE, Rogers-Chrysler G, Clay M, Pittelko L, Therkelsen D, Kim D, McCullough J: A phased consent policy for cord blood donation. Transfusion 2002;42:1268-1274.

24 American Academy of Pediatrics. Work Group on Cord Blood Banking: Cord blood banking for potential future transplantation: subject review. Pediatrics 1999;104:116-118.

25 Jefferies LC, Albertus M, Morgan MA, Moolton D High deferral rate for maternal-neonatal donor pairs for an allogeneic umbilical cord blood bank. Transfusion 1999:39:415-419.

26 McCullough J, Clay M: Reasons for deferral of potential umbilical cord blood donors. Transfusion 2000;40:124-125. 